\section{Andrej Žmegač Marijana Vojtić}

Institut za povijest umjetnosti, Zagreb

\title{
Dvorac Gornje Oroslavje
}

Izvorni znanstveni rad / Original scientific paper

UDK / UDC: 728.82(495.7 Oroslavje)

1. 7. 2013.

Ključne riječi: dvorac, kapela, prenamjena, Gornje Oroslavje, Vranyczany

Key words: castle, chapel, conversion, Gornje Oroslavje, Vranyczany

U radu je riječ o dvorcu Gornje Oroslavje koji je nakon Drugoga svjetskog rata nastradao u požaru te je srušen gotovo do temelja. Prema dosad djelomice neiskorištenoj dokumentaciji (arhivski dokumenti iz 18. stoljeća, arhitektonske snimke iz dvadesetih godina 20. stoljeća), iznose se hipoteze o građevnom rastu dvorca koji nije imao očigledno vidljivu stariju jezgru, moguću prvobitnu kuriju. Jedna je od hipoteza i postojanje trokrilnog sklopa sogradnim zidom na četortoj strani, na što upućuje tzv. jozefinski premjer. Posebna se pozornost posvećuje pitanju smještaja dvorske kapele, za koju postoje naznake da se nalazila u rizalitno istaknutom tijelu u jugozapadnom krilu. Autori naposljetku opisuju intervenciju poduzetnika Prpića nakon Prvoga svjetskog rata, ističući da je ona za dvorac značila pogubnu prenamjenu.

Dvorac Gornje Oroslavje, od kojega nije ostalo gotovo ni traga, bio je jedan od reprezentativnih primjera naše feudalne stambene arhitekture. Zbog toga valja žaliti što danas nije moguće njegovo neposredno izučavanje, kao što je i neobično da je tako znatna građevina zapravo nestala u razmjerno nedavno doba. To je dakako bio završni čin njezine nesretne sudbine u 20. stoljeću, u kojoj se bilo nanizalo više za nju tragičnih odluka i događaja. Unatoč razmjerno kasnom nestanku dvorca, činilo se da su raspoloživi podaci o njemu vrlo fragmentarni i oskudni. ${ }^{1}$ No intenzivno istraživanje u tom smjeru iznijelo je na vidjelo ipak obilje vrijednih dokumenata odnosno podataka te omogućilo ovaj pokušaj cjelovitog prikaza i tumačenja njegova povijesnog izgleda i prenamjene.

Kako je poznato, ${ }^{2}$ u Oroslavju su stajala dva reprezentativna dvorca, svaki u svojem perivoju, a među njima je na raskrižju cesta stajala župna crkva. Danas još postoji trokrilni kasnobarokni dvorac Vojkovićã (Donje Oroslavje), dok je prema jugoistoku lokacija nekadašnjeg dvorca Gornje Oroslavje. Bila je, kako znademo, ${ }^{3}$ riječ o tradicionalno koncipiranoj građevini s četiri jednokatna krila što su zatvarala unutarnje dvorište; na uglovima su stajale cilindrične kule. Prema razlikama u prostornoj, odnosno stilskoj koncepciji može se zaključiti da je Gornje Oroslavje bilo starije od dva tamošnja dvorca, a da mu se Vojkovićev dvorac pridružio po svemu sudeći u drugoj polovini 18. stoljeća. ${ }^{4}$

Podaci o postojanju kurije Oroslavje sežu još u 16. stoljeće, ${ }^{5}$ no ostaje nejasno je li time izričito potvrđeno postojanje i odgovarajuće građevine. Kao što je poznato, u drugoj se polovini stoljeća u Zagorju odvija proces kurijalizacije, tj. raspadanja vlastelinstava na manje posjede (kurije), na kojima su u pravilu postupno izgrađena i njihova istoimena upravna sjedišta. Godine 1614. dotadašnji vlasnici Ratkaji prodali su kuriju Oroslavje Juliju Čikuliniju, a isprava o tome nedvosmisleno spominje kuriju kao građevinu. ${ }^{6}$ Teško je, međutim, sa sigurnošću govoriti o vezi te kurije s kasnijim dvorcem u smislu da bi njezino tijelo bilo uključeno u proširenu višekrilnu građevinu, kako je to nerijetko slučaj.? Naime, prema arhitektonskim snimkama dvorca s početka dvadesetih godina 20 . stoljeća i kasnijima, iz pedesetih, ${ }^{8}$ ne 
može se naočigled prepoznati krilo, tj. tijelo koje bi, primjerice drukčijom debljinom zidova i drukčijim svođenjem, bilo različito od ostatka sklopa. Čini se da ni imenovanje građevine u povijesnim dokumentima neće doprinijeti da se naznači doba kada je pretpostavljena prvotna jednokrilna građevina bila pretvorena u višekrilnu - primjerice isprva uporabom pojma curia, a od nekog doba pojma castellum; upravo iz ranog doba poznajemo ispravu u kojoj se za Oroslavje kaže "castellum seu curia«, dvorac ili kurija. ${ }^{9}$

Pogleda li se pomnije spomenute tlocrte oroslavskog dvorca iz dvadesetih i pedesetih godina prošlog stoljeća, može se zapaziti kako kule nisu bile sve jednako vezane uz uglove građevine: ona južna imala je uobičajen spoj tako da su dva pročeljna zida bila povezana kratkim zakošenim zidom, u kojem su se nalazila vrata za ulaz u kulu. Tri preostale kule, međutim, na posve su se neuobičajen način vezivale za uglove, jer su oni izbijali u njihovu unutrašnjost. Iz takve se situacije može zaključiti samo jedno: južna je kula jedina bila nastala kao dio jedinstvene zamisli istodobno $s$ krilom, te je s njime logično i »organski«povezana. Preostali uglovi građevine u nekom su razdoblju stajali slobodno, a onda su im prigrađene kule, i to tako da su obuhvatile postojeće uglove. Nakon toga se očigledno bilo pokazalo kako sami vrhovi stvaraju teškoće u praktičnom korištenju ovih prostora, te su stoga bili zaobljeni, što je jasno vidljivo $\mathrm{u}$ arhitektonskim snimkama.

Ako su tri uglovne kule bile dograđene postojećem dvorcu u sklopu sekundarne oblikovne zamisli, gdje su umjesto izvorne obrambene imale tek amblematsku, odnosno simboličku ulogu (u smislu označavanja tradicije, moći, gospodstva itsl.), pozornost privlači ona četvrta kula. Ona je još mogla potjecati iz doba obrambenih potreba i eventualno pripadati nekoj starijoj jezgri kasnijeg dvorca. ${ }^{10}$ U razmatranju tih hipoteza valja se, nažalost, osloniti tek na arhitektonske snimke građevine, jer je njezinim rušenjem nestala mogućnost za istraživanje odgovarajućih pojedinosti na zidanoj strukturi.

Znakovitu pojedinost za tumačenje povijesnog rasta neke građevine mogu tvoriti nejednake širine različitih krila. U našem slučaju može se zapaziti da su sjeveroistočno i jugoistočno krilo šire od preostalih dvaju krila. Logična bi hipoteza bila da je jedno od tih širih krila (ili oba) predstavljalo tijelo pretpostavljene prvotne kurije; u njezinu sklopu mogla je stajati i kula, južna kula budućega četverokrilnog dvorca. Dakle, mogla je biti riječ o jugoistočnom krilu s kulom, čemu valja pribrojiti i tijelo stubišta na sjevernoj strani; to stubište skromnih dimenzija služilo je u kasnijem četverokrilnom sklopu kao sporedno, odnosno kao stubište za poslugu, a izvorno je moglo služiti vertikalnoj komunikaciji jednokrilne građevine. Osim takve kurije, opravdano bi za rano razdoblje bilo pretpostaviti postojanje i dvokrilne građevine koja bi obuhvaćala spomenuta šira krila (jugoistočno i sjeveroistočno) kasnijeg dvorca.

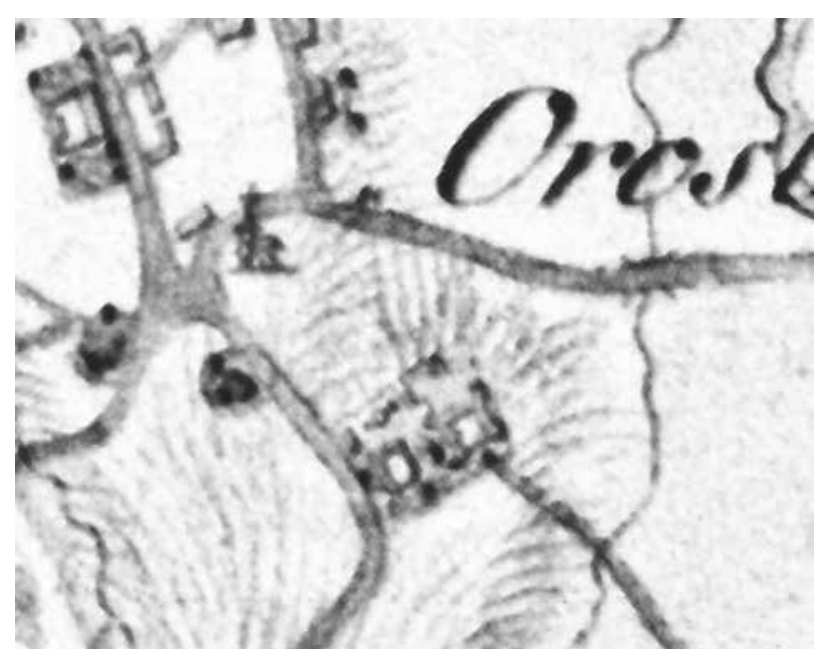

Tzv. jozefinski premjer, 1784. / The so-called "Josephinian survey"

Međutim, kako je bilo naznačeno, dokumentacija iz suvremenog doba ne upućuje jasno na takav građevni razvoj. Razmjerno je zbunjujuće što su sva četiri krila dvorca bila svođena istim tipom svoda - u prizemlju je bila riječ 0 »češkim«, a na katu o zrcalnim svodovima. ${ }^{11}$ Riječ je o tipovima svođenja karakterističnima za 18. stoljeće, te se postavlja pitanje kada zapravo pada uspostava četverokrilnog dvorca u poznatom obliku i s takvim svođenjem. Iz godine 1746. poznajemo, naime, popis stvari u oroslavskom dvorcu, gdje se navodi veći broj prostorija prema njihovoj namjeni, te se spominje i više "turna«, kula; mogli bismo zaključiti da je u to doba već stajao višekrilni dvorac, i to s naknadno dograđenim kulama. $U$ popisu se spominje $i$ »turn ober vrat«, ali to neće biti tornjić nad ulazom u jugozapadnom krilu, jer je u kuli bilo pohranjeno odviše stvari. ${ }^{12}$ Tlocrtno je dvorac već mogao imati svoj konačni oblik, a nejasno ostaje kakvo mu je bilo nadsvođenje $\mathrm{u}$ to doba. Svakako se u spomenutom popisu pojedine prostorije navode kao nadsvođene, a spomenute su manje takve prostorije (»vu bolticzi polek«, »vu dolni bolticzi pod goszpinum hisum, vu male pevnicze pod boltum«itd.).

Na drukčiju mogućnost tumačenja građevnog razvoja oroslavskog dvorca upućuje njegov prikaz u tzv. jozefinskom premjeru iz 1784. godine. Ondje je organizacija dvorca bitno drukčija nego što je poznajemo iz katastarske snimke iz 19. stoljeća te iz suvremenih arhitektonskih snimki. Prilaz, naime, ne vodi s jugozapada dugom prilaznom osi, nego umjesto toga ondje stoji neka druga četverokutna građevina $s$ unutarnjim dvorištem, veličinom tek nešto skromnija od dvorca. O njoj iz povijesnih podataka ne znademo ništa, a prema nejasnom crtežu moglo bi se reći da je imala jedno krilo i zidom ograđen pripadajući prostor. Možda je ovdje bila riječ o prvotnoj oroslavskoj kuriji koja je izgradnjom novog dvorca izgubila funkciju te bila pretvorena u pomoćnu, tj. gospodarsku zgradu. Prilaz pak dvorcu vodi prema 


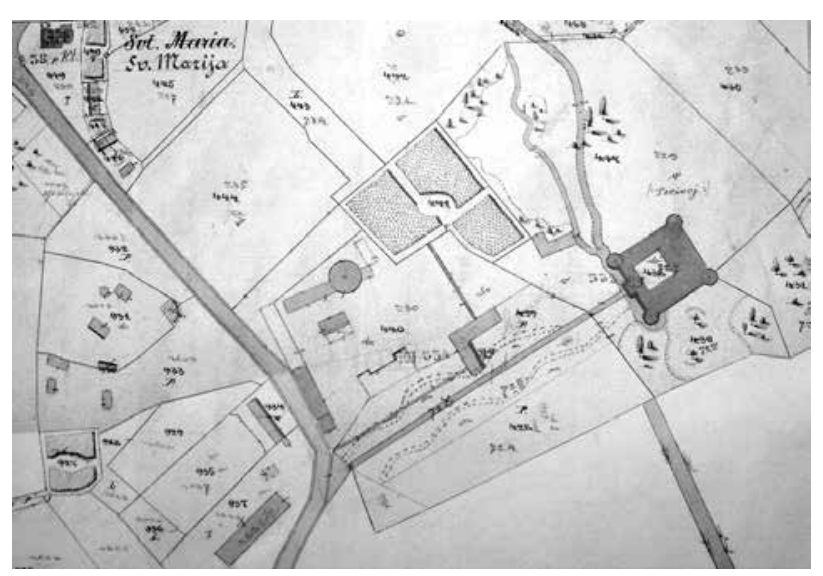

Katastarska snimka, 19. stoljeće (Hrvatski državni arhiv, Zagreb) / Land registry survey map, 19th century (Croatian State Archives, Zagreb)

njegovu jugoistočnom pročelju gdje se očigledno nalazio ulaz u građevinu. Crtež dosta jasno pokazuje dvorac kao trokrilnu građevinu, s ogradnim zidom na jugoistočnoj, prilaznoj strani; tu bi posrijedi mogla biti već tipično barokna organizacija prostora s obzirom na središnju os. ${ }^{13}$ Čini se također da se u jugozapadnom krilu prepoznaje rizalitno izbačeno tijelo poznato iz kasnijeg doba.

Koliko taj prikaz valja smatrati vjerodostojnim, teško je reći. Bilo bi, ponajprije, donekle neuobičajeno da su takvoj trokrilnoj građevini naknadno dograđene cilindrične kule. ${ }^{14}$

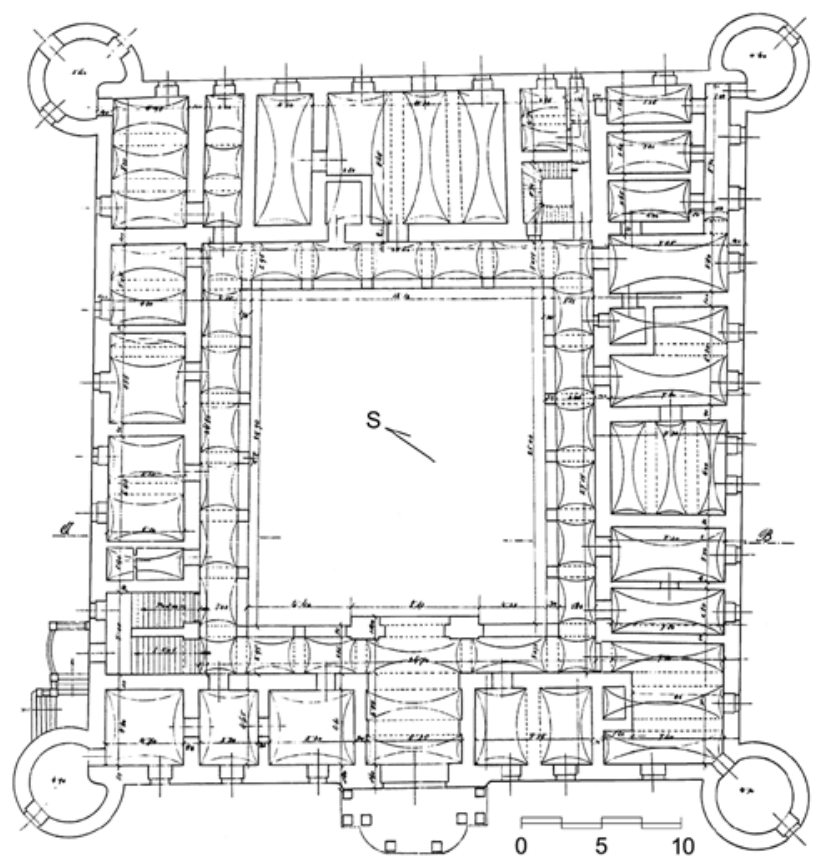

Tlocrt prizemlja, dvadesete godine 20. stoljeća (Ministarstvo kulture Republike Hrvatske, Uprava za zaštitu kulturne baštine) / Ground floor plan, nineteen-twenties (Ministry of Culture, Republic of Croatia, Directorate for the Protection of Cultural Heritage)
Potom, sklop bi bio nejednakih krila jer je, kako je rečeno, postojala znatna razlika u širini između sjeveroistočnog te sjeverozapadnog i jugozapadnog krila. U osi sklopa, u središnjem, sjeverozapadnom krilu, očekivalo bi se dvoranu, a suvremene arhitektonske snimke ne pokazuju njezino postojanje. ${ }^{15}$

Drukčije tumačenje građevnog razvoja dvorca mogli bismo uspostaviti na osnovi nacrta s početka dvadesetih godina, prije adaptacije dvorca u tekstilnu tvornicu. Ondje se jasno mogu odčitati širine pojedinih krila i uglovnih kula. Sjeverozapadno i jugozapadno krilo jednake su širine $(10 \mathrm{~m})$, sjeveroistočno je najšire $(13,5 \mathrm{~m})$, a jugoistočno se krilo sužava od 12,6 m na spoju sa sjeveroistočnim do 11,7 na spoju s jugozapadnim krilom. Podrum se proteže ispod cijele dužine sjeverozapadnog pročelja. ${ }^{16}$ Tri kule (istočna, zapadna i južna) približno su jednakog promjera $(6,6 \mathrm{~m}$, $6,9 \mathrm{~m}, 6,7 \mathrm{~m})$, dok je sjeverna kula vidljivo šira $(7,4 \mathrm{~m})$. Polazeći od smještaja podruma i glavnog stubišta, moguće je pretpostaviti sjeverozapadno krilo kao najstarije. Vidljivo je kako se u prizemlju navedenoga krila trijem produžuje u sjeveroistočno krilo sve do sjeveroistočnog pročelja. Na katu pak krilo završava kvadratičnom prostorijom u punoj širini krila, gotovo najvećom prostorijom u dvorcu (jednake površine kao i »kapela«). Nije svođena, tj. ima drveni grednik te je vezana za najveću, sjevernu kulu. Na zapadnom završetku krila nalazi se glavno stubište te manja kvadratična prostorija s ulazom u zapadnu kulu. Na fotografiji s kraja 19. stoljeća vidljivi su kasnije oblikovani (klasicistički) lukovi zidanog

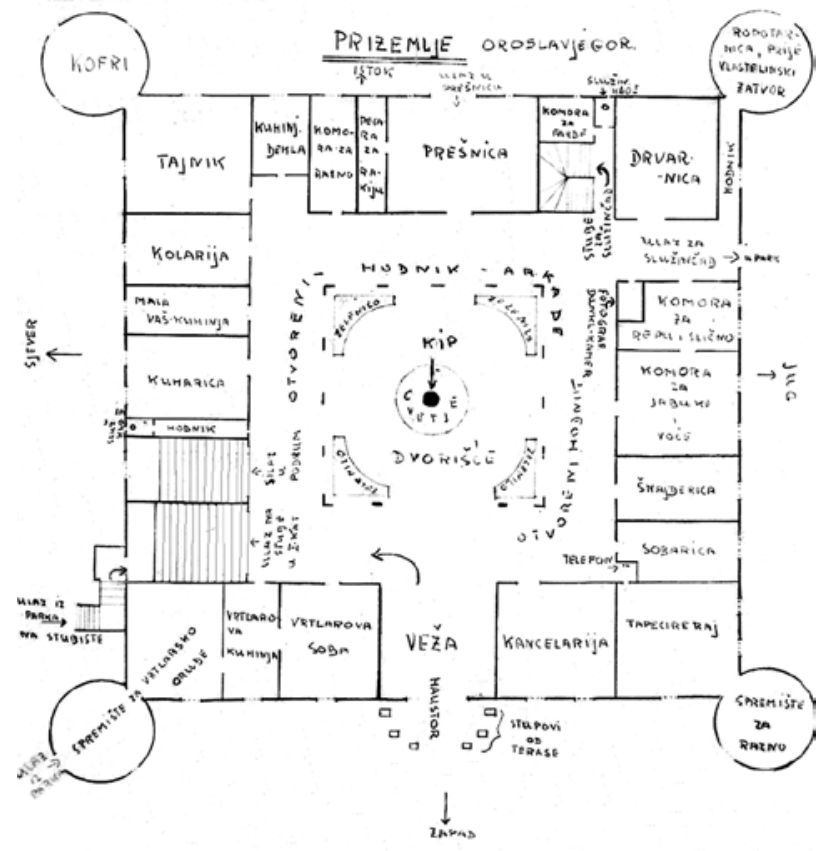

Tlocrt prizemlja, crtež Milana Vranyczanyja (Hrvatski državni arhiv, Zagreb) / Ground floor plan, drawing by Milan Vranyczany (Croatian State Archives, Zagreb) 


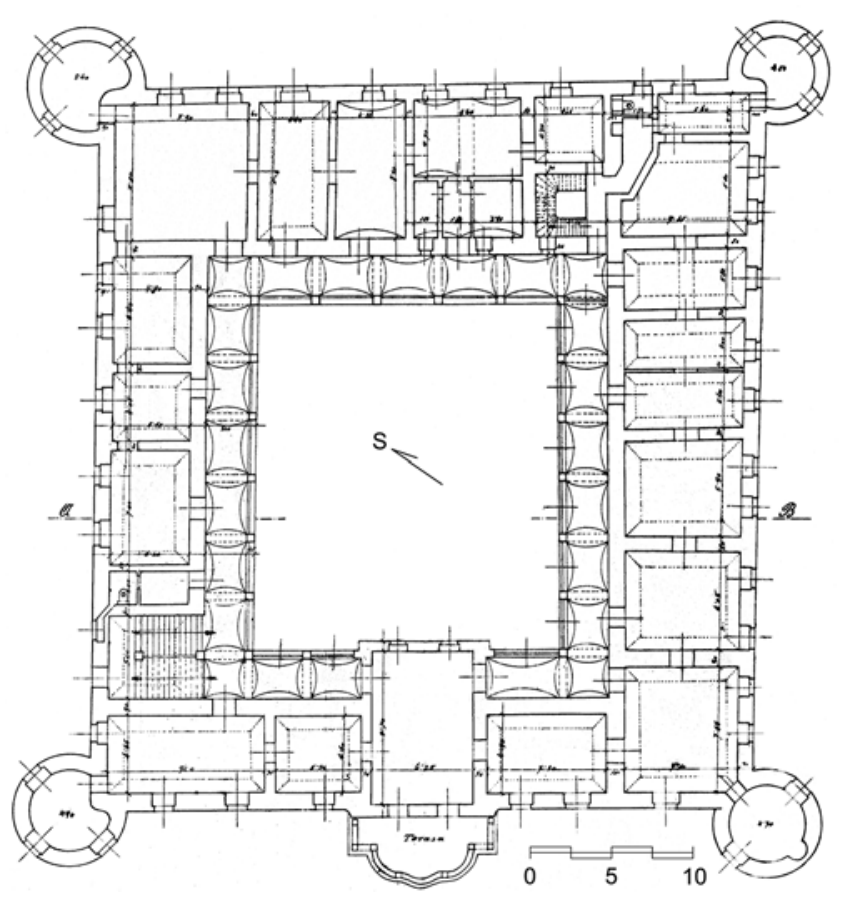

Tlocrt kata, dvadesete godine 20. stoljeća (Ministarstvo kulture Republike Hrvatske, Uprava za zaštitu kulturne baštine) / Plan of the first floor, nineteen-twenties (Ministry of Culture, Republic of Croatia, Directorate for the Protection of Cultural Heritage)

trijema, iz čega bi se moglo pretpostaviti da je izvorno trijem mogao biti i drven. Postoje dakle naznake da je dvorac izvorno mogao biti i jednokrilan s drvenim trijemom, a bez kula. Međutim, spoj sjeverozapadnog i jugozapadnog krila ne daje nam jasnu naznaku da je jugozapadno krilo izgrađeno naknadno. To krilo ima sličnu prostornu organizaciju: u prizemlju trijem završava prostorom koji je oblikovno sličan završetku sjeverozapadnog trijema (u krajnjoj južnoj prostoriji vidljive su kasnije intervencije). Na katu krilo završava kvadratičnom prostorijom širine cijeloga krila, iz koje se ulazi u južnu kulu. To omogućuje pretpostavku da je dvorac izvorno mogao biti i L-oblika, tj. da su sjeverozapadno i jugozapadno dva najstarija krila dvorca. No, do zanimljive pretpostavke možemo doći obratimo li pozornost na debljine vanjskih zidova dvaju spomenutih krila. U sjeverozapadnom krilu kontinuirano pratimo debljinu zida od $100 \mathrm{~cm}$, dok u jugozapadnom krilu debljina zida od zapadne kule do »kapele« iznosi $115 \mathrm{~cm}$, a nakon kapele prema južnoj kuli samo $90 \mathrm{~cm}$. Uzimajući u obzir da i sama »kapela« prema zapadnoj kuli ima tanji zid od $70 \mathrm{~cm}$, a prema južnoj kuli deblji zid od $90 \mathrm{~cm}$, mogli bismo pretpostaviti da je dvorac izvorno mogao biti dvokrilan, L-oblika, s kapelom kao završnim dijelom jugozapadnoga krila.

Jasnije je, ali i drukčije, situacija dvorca onda prikazana na katastarskom planu u 19. stoljeću. Nestalo je četverokutne građevine što je stajala pred dvorcem, a ondje je uspostavljena duga prilazna staza što vodi prema rizalitu

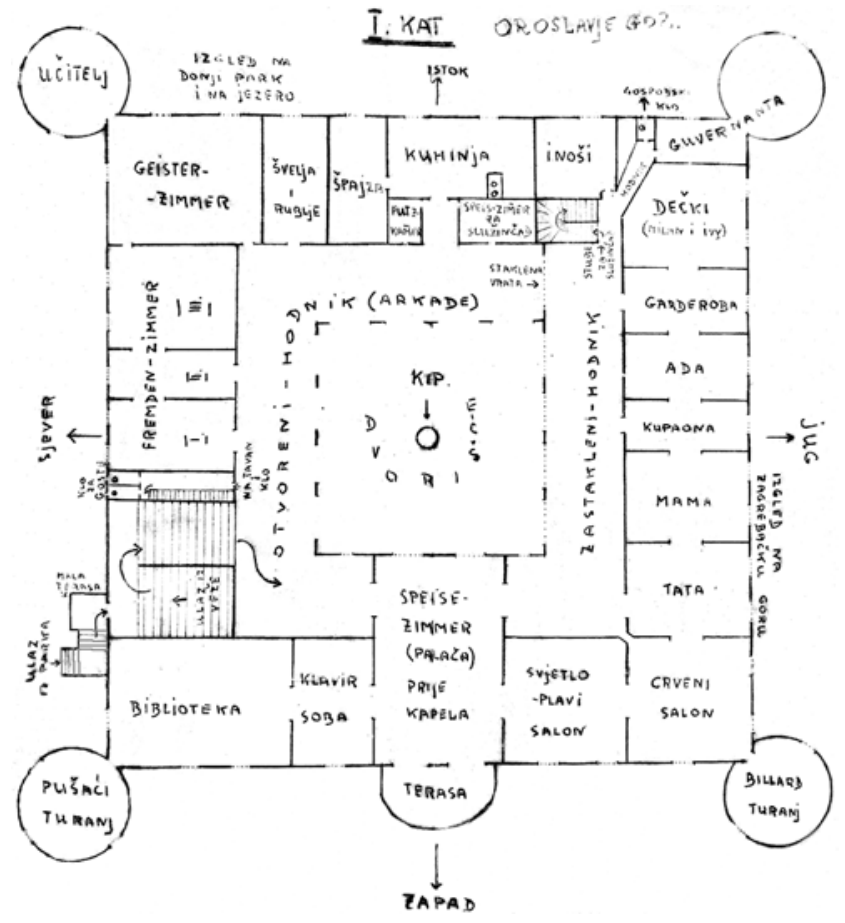

Tlocrt kata, crtež Milana Vranyczanyja (Hrvatski državni arhiv, Zagreb) / Plan of first floor, drawing by Milan Vranyczany (Croatian State Archives, Zagreb)

i, očigledno, ulazu u dvorac; riječ je, dakle, o situaciji koju poznajemo iz suvremenog doba. $U$ masi same građevine jasno se razlikuju širine pojedinih krila, pa su te razlike ponešto i prenaglašene. To je doba kada je dvorac bio u posjedu obitelji Sermage (1746.-1885.), nakon čega ga kupuje Ljudevit Vranyczany.

O dobu Vranyczanyjeva posjedovanja dvorca dragocjene podatke ostavio je njegov sin Milan. ${ }^{17}$ Osobito su zanimljivi shematski izvedeni tlocrti kojima je glavna svrha predočiti namjenu i način korištenja pojedinih prostorija dvorca. Očekivano, prizemlje su zauzimali stanovi za služinčad (»kuharica«, »šnajderica«, »tajnik« itd.) i različite radionice ${ }^{18}$ te spremišta (»mala vaš kuhinja«, »tapecireraj«, »ropotarnica, prije vlastelinski zatvor« itd.). Tlocrt kata onda pokazuje kako je pojedinim krilima bila dodijeljena različita uloga, očito prema orijentaciji i položaju u dvorskom sklopu. Primjerice, sjeveroistočno je krilo bilo, moglo bi se reći, servisno, jer su se ondje nalazile kuhinja i smočnica, ali su u kulama na krajevima krila stanovali i učitelj odnosno guvernanta. Oni su u dvorcu boravili očigledno kako bi poučavali Vranyczanyjevu djecu. »Obiteljsko « krilo pak bilo je ono jugoistočno gdje su se nizale sobe roditeljā te njihove djece; ovo je krilo zasigurno bilo najkomfornije jer se u njegovu središtu nalazila kupaonica, a hodnik prema dvorištu bio je zaštićen tako što su arkade ondje bile zastakljene. Nasuprotno sjeverozapadno krilo obuhvaćalo je gostinske sobe i glavno, prostrano stubište. Napokon, jugozapadno je 


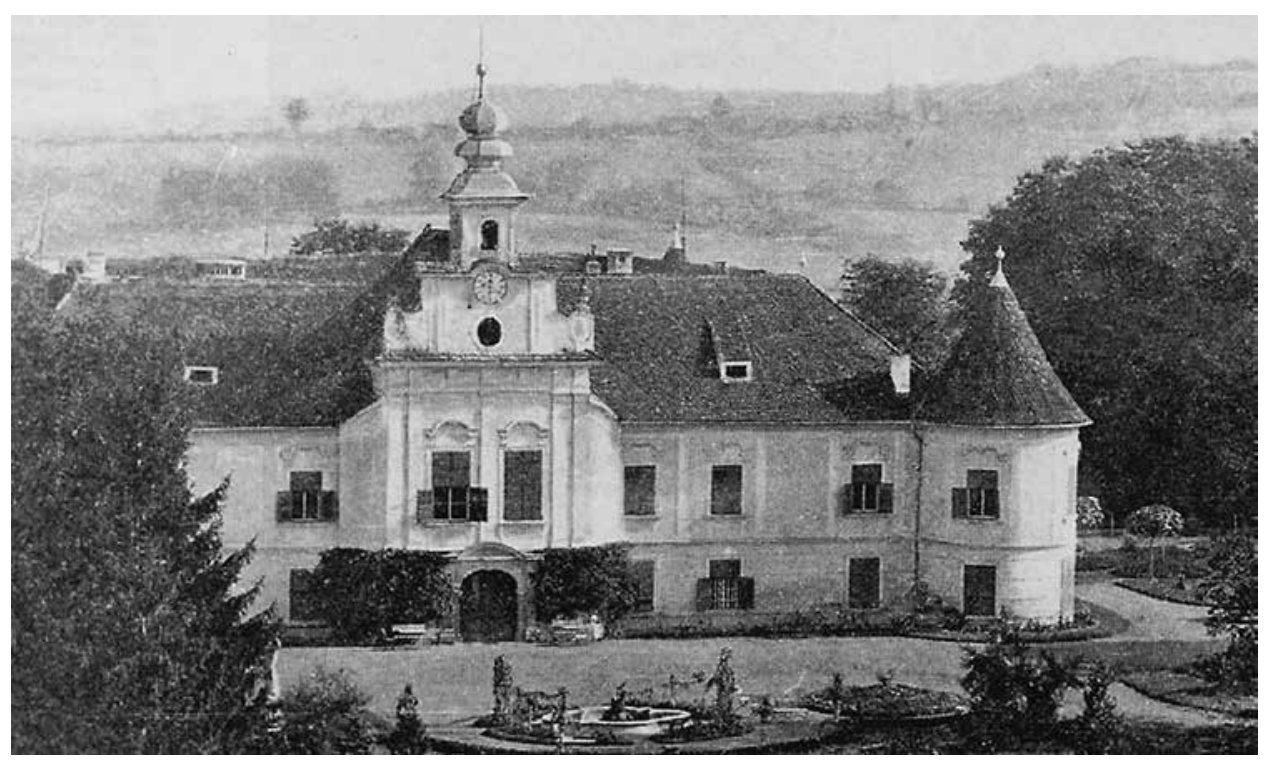

Jugozapadno pročelje prije dogradnje altane / Southwest front before the altana was added

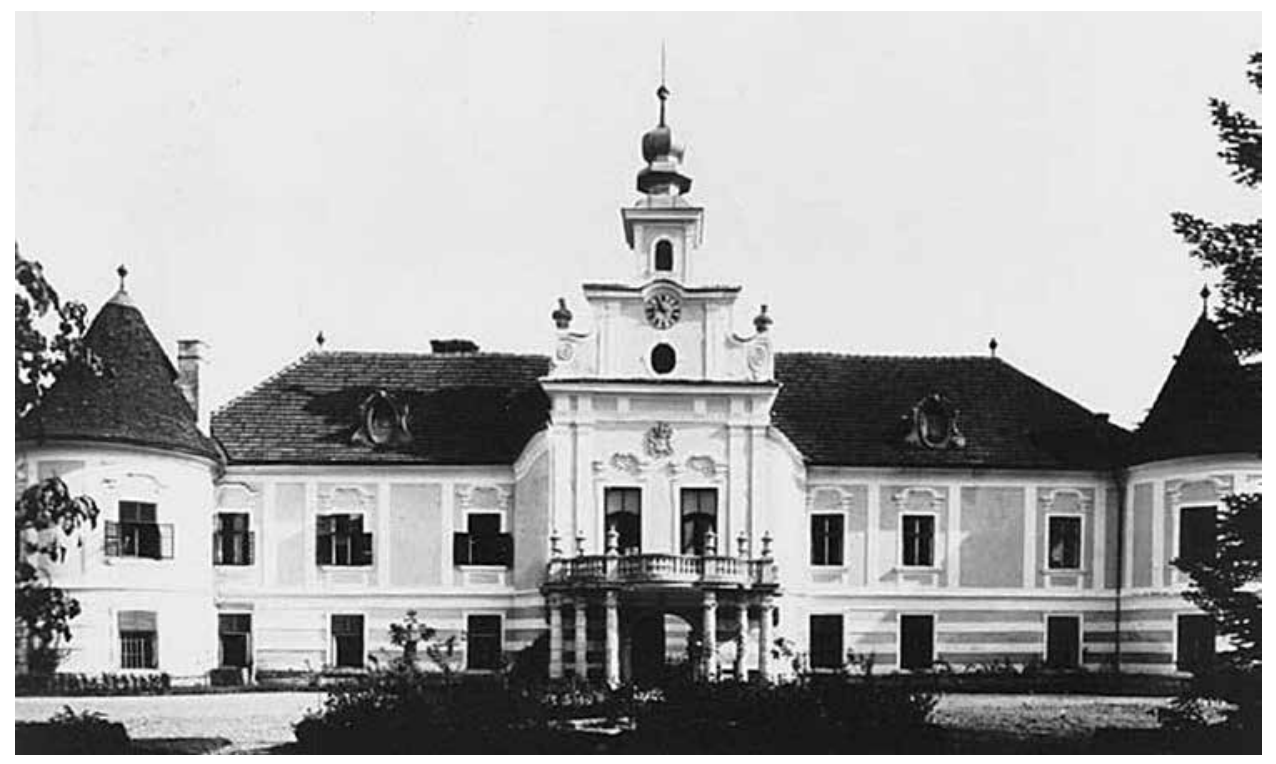

Jugozapadno pročelje nakon dogradnje altane / Southwest front after the altana was added krilo kao ulazno bilo glavno i reprezentativnije od ostalih te je služilo društvenim sadržajima.

U osi krila stajalo je rizalitno istaknuto tijelo za koje Milan Vranyczany navodi kako je bila riječ o prijašnjoj dvorskoj kapeli. To je tijelo bilo istaknuto ne samo na pročelju nego i s dvorišne strane, a većom visinom i zasebnim krovištem odvajalo se od ostatka krila. U starijim dokumentima spomen na dvorsku kapelu nalazimo u opisu iz 1746. godine, a ondje se navodi i kapelanova soba (»vu kapelicze«, "vu capellanszke hise «). ${ }^{19}$ Popis iz 1782. godine upućuje onda jasno na to da je kapela bila dvoetažna, kako je to i bilo uobičajeno u većim dvorcima; u opisu prizemlja navodi se kako je uz kapelu bila i sakristija (»vu kapeliczi, y sakrestie«). ${ }^{20}$ Zanimljiv navod o kapeli nalazimo i u procjeni iz 1797. godine, gdje je riječ o stubištu kraj kapele (»in gradibus penes capellam «). ${ }^{21}$ Valjda je tu bilo posrijedi veliko stubište u sjeverozapadnom krilu.
Ipak prvotni smještaj kapele nije posve jasan. Pod pretpostavkom da se nalazila u rizalitno istaknutom tijelu $\mathrm{u}$ jugozapadnom krilu, u 19. je stoljeću moralo biti uspostavljeno neuobičajeno stanje, vidljivo u katastarskoj snimci. To bi značilo da je glavni prilaz usmjeren prema kapeli, da je njezino prizemlje pretvoreno u vežu kojom se prolazi u dvorište te da je dokinuta njezina dvoetažna organizacija. Također, po položaju središnja dvorana dvorca, smještena nad glavnim ulazom, ujedno i najveća, ne bi bila korištena kao mjesto društvenih okupljanja, nego kao mjesto za molitvu, što je posve neuobičajeno. Tema dvorske kapele, kao i građevni rast dvorca od moguće manje jezgre do četverokrilnog sklopa, pitanja su koja je nužno razrješivati uz pomoć starije dokumentacije, no razložito je ujedno oprezno zaključivati na osnovi često nejasnih navoda.

Prema svjedočanstvu Milana Vranyczanyja, njegov je otac središnjem rizalitu oko 1904. godine dao dograditi altanu, 


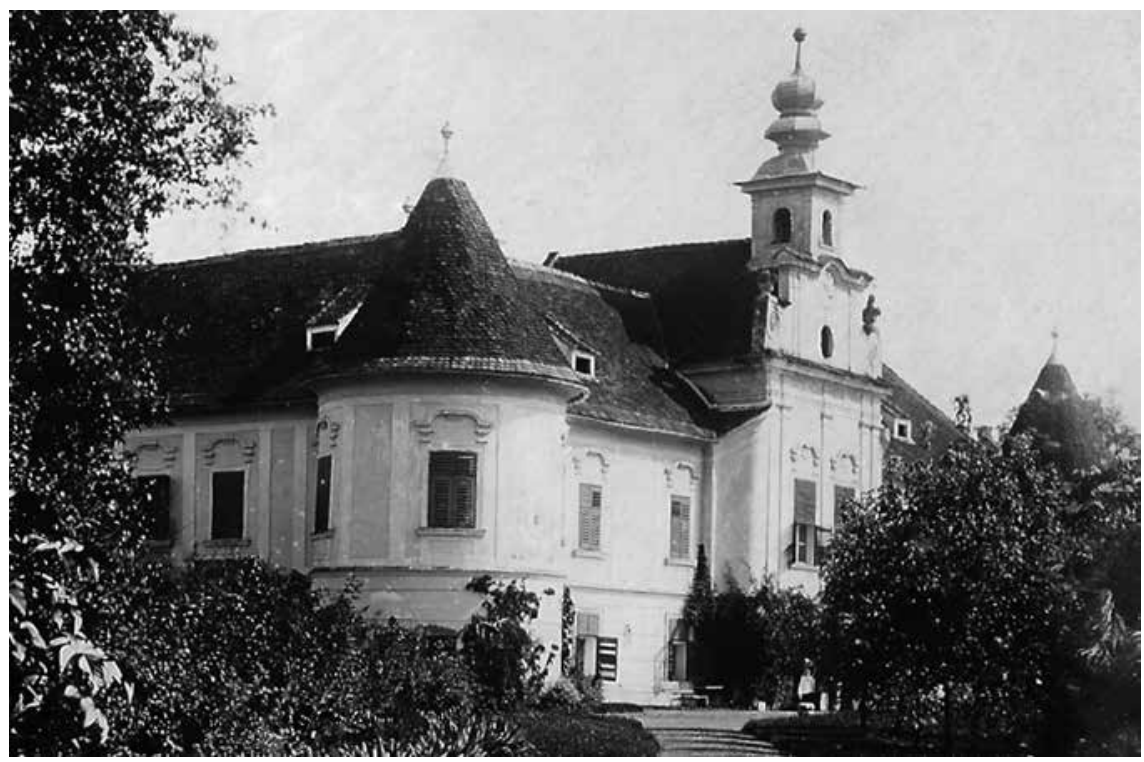

Zapadna kula i glavno pročelje / West tower and main front

pomenutoj, zapadnoj kuli nalazile su se na zidovima i svodu uljene slike u štuko-okvirima, s prikazima pobjede Eugena Savojskog nad Turcima kod Beograda 1717. godine. $U$ stubišnom prostoru bilo je mjesto medaljona sa simboličkim likovima i oroslavskim dvorcem u pozadini. Kako je navedeno u izvješću iz 1949. godine, u prostoru glavnog stubišta svod je bio oslikan alegorijskim iluzionističkim slikama s motivima četiriju strana svijeta. Pred stubištem su stajala bogato oblikovana

prema projektu Ignjata Fischera. Ta neobarokna altana na osam stupova imala je balustradu s vazama, naglasivši ionako bogato oblikovani rizalit $s$ visokim zabatom i tornjićem. Vranyczanyjevoj obnovi valja pribrojiti i neobarokno preoblikovanje krovnih prozora. Tlocrti građevine iz toga doba pokazuju da je dvorac imao više ulaza: uz glavni, Vranyczany je otvorio i vanjski ulaz u stubište sjeverozapadnoga krila, potom su ulazi postojali u sjeveroistočnom i jugoistočnom krilu, te u zapadnu kulu. Milan Vranyczany tumači tijelo u jugozapadnom krilu kao bivšu kapelu koju je njegov otac pretvorio u blagovaonicu, postavivši parket umjesto dotadašnjega kamenog poda. Prema njegovu tlocrtu, istočno od »kapele« nalazili su se »svijetloplavi« i »crveni« salon, očigledno prozvani prema boji namještaja ili tapeta. ${ }^{22}$ Zapadni dio krila zapremale su glazbena soba i knjižnica, a društvenu namjenu ovoga krila dopunjavale su sobe u uglovnim kulama, namijenjene igranju biljara odnosno pušenju. U posljednjes-

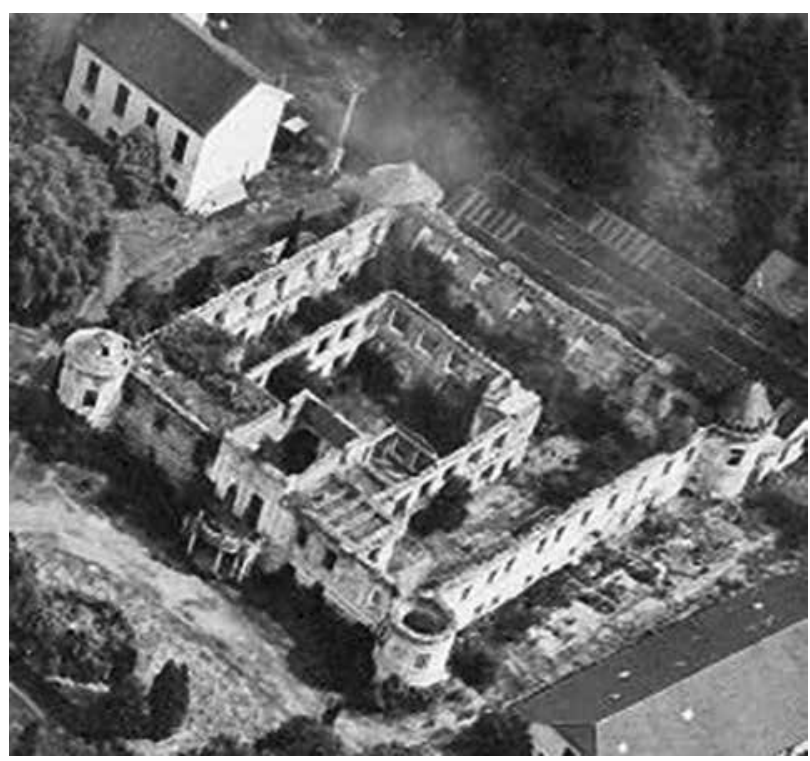

vrata od kovanog željeza. U veži su pak bila četiri medaljona $\mathrm{u}$ štuku, ispunjena figurama. ${ }^{23}$

Vranyczany je dvorac (zajedno sa svim namještajem i slikama) 1921. godine prodao poduzetniku Milanu Prpiću, koji je, pregradivši ga, ondje uredio tekstilnu tvornicu »Preslica«. Arhitektonske snimke iz toga doba točno prikazuju građevinu i planirane zahvate na njoj: Prpić je krila dvorca želio pretvoriti u tvorničke hale, pa je stoga u prizemlju i na katu dao srušiti većinu pregradnih zidova te čak i unutarnje zidove dvaju krila, jugoistočnog i sjeverozapadnog. Ti su zahvati dobro vidljivi (označeni žuto) na tlocrtu i presjeku dvorca s početka dvadesetih godina; nacrte su potpisali inženjeri S. Batušić i G. Košutić iz Građevnog poduzetništva Skopal, Juričić i Batušić, Zagreb. ${ }^{24} \mathrm{Na}$ mjesto unutarnjih uzdužnih zidova došao je niz drvenih nosača. Kako je to vidljivo $\mathrm{u}$ arhitektonskim snimkama, zbog uklanjanja većine zidova morali su dakako biti uklonjeni i svodovi obiju etaža dvorca. Umjesto svodova bila je sada izvedena drvena međukatna konstrukcija, odnosno strop prvoga kata. Arkadni zid prema dvorištu bio je preinačen tako što su arkadni otvori prizemlja smanjeni $u$ format pravokutnih vrata. Ulazno, jugozapadno krilo ostalo je nedirnuto adaptacijskim zahvatima pa je očigledno da mu je ostavljena uloga reprezentativnog, odnosno sada upravnog trakta. S vremenom se, čini se, bilo pokazalo da prostorni kapacitet dvorca nije dostatan za proizvodnju te su uz sjeveroistočni njegov zid prigrađene najprije prizemne kućice (strojarnica, bojadisaonica), a poslije umjesto njih industrijska hala s karakterističnim shed-krovom. Dvije skromne kućice podignute su i uz uglove unutarnjeg dvorišta.

Nakon Drugoga svjetskog rata započinje se s preuređenjem dvorca u radničko odmaralište; radove vodi Glavni 
odbor Jedinstvenih sindikata Hrvatske, koji javlja Konzervatorskom zavodu »da su sve umjetnine ostale netaknute«, a malo zatim je riječ o »ostacima umjetnina«. Iz Karamanovih dopisa Sindikatu vidi se da su s prozora prizemlja demontirane kovane rešetke te da su oštećene zidne slike i štukatura podizanjem novih pregradnih zidova. ${ }^{25}$

Godine 1949. izbio je požar i velikim dijelom uništio dvorac. Razmjerima oštećenja nesumnjivo je doprinijelo to što je Prpić prijašnje zidane konstrukcije (zidove, svodove) uklonio i nadomjestio drvenim nosačima i stropovima. Povjerenstvo Konzervatorskog zavoda u pregledu 5. srpnja 1949. konstatira da je tek glavno, jugozapadno krilo uglavnom ostalo pošteđeno od požara. ${ }^{26}$

Idućih godina obnovljena je zamisao o preuređenju dvorca, ovaj put u dom kulture; o tome je riječ u izvješćima Grete Jurišić. ${ }^{27}$ Namjeravalo se ondje urediti kinodvoranu, čitaonicu, kantinu i sl. Kako tada nisu bili poznate snimke iz dvadesetih godina, navedena je potreba snimanja građevine kako bi se moglo započeti s projektiranjem. Napokon, 1957. godine Greta Jurišić izrađuje projekt za adaptaciju dvorca u traženu namjenu. Bila je riječ o slobodnom projektiranju u »ispražnjenim « krilima dvorca, s obzirom na to da povijesni raspored prostora u dvorcu, iz doba prije Prpićeve adaptacije, očigledno nije bio dovoljno poznat. Druga adaptacija nije bila izvedena te su ostaci građevine ubrzo srušeni. Danas postoji samo još sjeveroistočni zid s tragovima dviju uglovnih kula, kao dio preostale tvorničke hale. ${ }^{28}$

Povijesna sudbina Gornjeg Oroslavja pokazuje, prije svega, neobično zanimljiv građevni rast u starijem razdoblju, a onda i vrlo nesretan razvoj događaja u 20. stoljeću. On je ponajviše imao uzrok u adaptaciji dvorca za industrijsku namjenu, što je proveo poduzetnik Prpić nakon Prvoga svjetskog rata. Taj primjer ujedno podsjeća kako nesretne prenamjene i devastacije naše povijesne arhitekture nisu rezultat samo komunističkog razdoblja nego da su se pokatkad zbile i prije toga.

\section{BILJEŠKE}

1 Dvorac je spomenut u sljedećoj literaturi: STJEPAN BELOŠEVIĆ, $\check{Z} u$ panija Varaždinska i slob. i kralj. grad Varaždin, Zagreb, 1926., 59-60; GJURO SZABO, Kroz Hrvatsko zagorje, Izdanje Knjižare Vasić, Zagreb, 1939., 173-175; DRAGINJA JURMAN-KARAMAN, O profanoj arhitekturi zagorskog feuduma potkraj XVIII. stoljeća, Bulletin Instituta za likovne umjetnosti Jugoslavenske akademije znanosti i umjetnosti, 3 (1958.), 176-177; ANĐELA HORVAT, RADMILA MATEJČIĆ, KRUNO PRIJATELJ, Barok u Hrvatskoj, Sveučilišna naklada Liber, Zagreb, 1982., 94, 185.

2 VLADIMIR MARKOVIĆ, Barokni dvorci Hrvatskog zagorja, Nacionalna i sveučilišna biblioteka, Zagreb, 1995., 74; Umjetnička topografija Hrvatske. Krapinsko-zagorska županija, (ur.) Ivanka Reberski, Institut za povijest umjetnosti; Školska knjiga, Zagreb, 2008., 488-489.

3 ANĐELA HORVAT, RADMILA MATEJČIĆ, KRUNO PRIJATELJ (bilj. 1), 94; MLADEN OBAD-ŠĆITAROCI, Dvorci i perivoji Hrvatskoga zagorja, Školska knjiga, Zagreb, 1991., 216.
4 Godine 1746. navodi se dvorac s kulama, pa je tu nesumnjivo riječ o Gornjem Oroslavju. Po sudu više istraživača, dvorac Donje Oroslavje pripada pak kasnijem dobu, što je vidljivo, primjerice, u proporcioniranju glavnog prema bočnim krilima, srodno dvorcu u Stubičkom Golubovcu; V. Marković ga datira potkraj 18. stoljeća, govoreći o kasnobaroknom klasicizmu: VLADIMIR MARKOVIĆ (bilj. 2), 24, 75; A. Horvat ga datira u doba od 1770. do 1790.: ANĐELA HORVAT, RADMILA MATEJČIĆ, KRUNO PRIJATELJ (bilj. 1), 185.

Valja dodati da 1760. Petar Sermage ugovara izradu opeke »za Novi Dvory Oroslavie«: Hrvatski državni arhiv, Zagreb (dalje: HDA), Čikulini-Sermage, kut. 55, br. 4.7. Potvrdu za postojanje dvaju dvoraca donosi onda dokument iz 1780.: HDA, Vlastelinstvo Zabok-Oroslavje, kut. 27.

5 JOSIP ADAMČEK, Susjedgradsko-stubičko vlastelinstvo uoči seljačke bune 1573., Historijski zbornik, 19-20 (1966.-1967.), 149-150.

6 HDA, Čikulini-Sermage, kut. 3, br. 191, prijepis iz 1789.; navodi se »curia aedificata«.

7 Poput dvoraca Lobor, Bežanec, Mirkovec, Klenovnik, Maruševec i dr. 8 Ministarstvo kulture RH, Uprava za zaštitu kulturne baštine, Zagreb, planoteka, RZZ 90/285 A5 i A10.

9 HDA, Čikulini-Sermage, kut. 46, br. 5.8 (1623.). Ovdje se, dakle, izrazi koriste kao sinonimi, a srodno korištenje izraza »kastel« za jednokrilnu građevinu nalazimo i poslije, primjerice za kuriju Stenjevec: HDA, Čikulini-Sermage, kut. 41, br. 1.146 (1782.).

S druge strane, nije naodmet podsjetiti kako je Ignacije Beischlag, sastavljajući 1801. kartu Varaždinske županije, jednokrilne građevine dosljedno označio kao curia, a višekrilne kao castellum; ANDREJ ŽMEGAČ, Feudalna profana arhitektura. Vlastelinski gradovi (burgovi), dvorci, kurije, Umjetnička topografija Hrvatske. Krapinsko-zagorska županija, (ur.) Ivanka Reberski, Institut za povijest umjetnosti; Školska knjiga, Zagreb, 2008., 84.

10 Međutim, ne treba posve odbaciti ni mogućnost da je ta kula, premda različito vezana na ugao građevine, podignuta istodobno s ostalima. Među osobitostima pak u oblikovanju kula valja istaknuti da je ona sjeverna bila zamjetno veća od ostalih.

11 Jedino je malena skupina prostora na katu sjeveroistočnoga krila bila svođena plitkim bačvastim svodovima; na to gledamo tek kao na pojednostavljivanje oblika »češkog « svoda, a ne neku znakovitu pojavu u smislu građevnog razvoja. Hodnici su u obje etaže bili nadsvođeni »češkim« svodovima.

12 HDA, Čikulini-Sermage, kut. 23, br. 2149; v. i JOSIP MATASOVIĆ, Die Briefe des Grafen Sermage, Narodna starina, Zagreb, 1923., 311-342. 13 Poput dvorca Zajezda, nastalog oko 1740. godine; v. VLADIMIR MARKOVIĆ (bilj. 2), 14.

14 Ipak, primjer trokrilnog barokno koncipiranog dvorca s četiri cilindrične kule je Lužnica.

15 Kao primjer načelno baroknoga, trokrilnog rasporeda, a nejednakih krila, valja navesti dvorac Mirkovec.

16 Vidjeti arhitektonske snimke iz doba nakon Drugoga svjetskog rata.

17 HDA, Vranyczany-Dobrinović, kut. 17, „Nekretnine koje su nekada bile vlasništvo članova obitelji Vranyczany«.

18 Zanimljivo je kako je u jugoistočnom krilu ubilježeno i postojanje tamne komore; Vranyczany je naime bio amaterski fotograf.

19 HDA, Čikulini-Sermage, kut. 22, br. 2149.

20 HDA, Čikulini-Sermage, kut. 41, br. 1.146 .

21 HDA, Čikulini-Sermage, kut. 39, br. 2796.

22 U crvenom salonu visjela je Bukovčeva slika Pet ćutila. Vranyczanyju je djevojka s ogledalom na tlu bila »odviše gola, pak je onda Bukovac, prema želji mog oca, njenu golu stražnjicu pokrio nekim velom«. HDA, Vranyczany-Dobrinović, kut. 14, sv. II, 170. Ovdje je vidljiva nepreciznost svjedočanstva jer formulacija ne odgovara posve Bukovčevoj kompoziciji. VERA KRUŽIĆ-UCHYTIL, Vlaho Bukovac. Život i djelo. 1855.-1922., Nakladni zavod Globus, Zagreb, 2005., 247, 374-375.

$23 »$ Oroslavlje, stanje dvorca u sklopu tekstilne tvornice (nekada vlasništvo Vranicany)«, izvješće od 5. VII. 1949. (Vrbanić, Pavelić, Stahuljak), Ministarstvo kulture RH, Uprava za zaštitu kulturne baštine, Zagreb, 1171-1949.

24 Bilj. 8. 
25 Ministarstvo kulture RH, Uprava za zaštitu kulturne baštine, Zagreb, 426-1948 (20. IV. 1948.), 555-1948 (22. V. 1948.).

26 Ministarstvo kulture RH, Uprava za zaštitu kulturne baštine, Zagreb, 1171-1949.: »Na pročelju je samo potkrovni vijenac na krilima i desnoj ugaonoj kuli uništen. Na srednjem prema naprijed istaknutom dijelu dvorca mali toranj (koji je ostao bez krova i potkrovnog vijenca) nagnuo se zajedno sa zabatom prema natrag u tolikoj mjeri da će se morati rušiti. To je nastalo uslijed toga što taj toranj počiva na željeznim traverzama, koje su podvučene ispod njega prilikom adaptacije dvorca 1921, a te su se traverze uslijed vrućine kod požara savinule. U prvom katu, idući od lijeva na desno (od zapada prema istoku) prva prostorija (unutar ugaone kule) sa uljenim slikama u stucco okvirima na zidovima i svodu uglav- nom je sasvim sačuvana. Druga i treća prostorija (smještene u lijevom krilu) imaju svod sa stuccaturom uglavnom još sasvim sačuvan. U četvrtoj prostoriji, koja je bila dvorana centralnog dijela, svod je potpuno propao. U petoj prostoriji (već u desnom krilu) svod sa stucco dekoracijom i ornamentalnom slikanom dekoracijom postoji. U sljedećim dvjema prostorijama, kao i u jugoistočnoj ugaonoj kuli stropovi i podovi su propali«. Za prostor stubišta kaže se da je »čađa kod požara prekrila pretežni dio svoda i sve zidove sa stuccom«.

27 Ministarstvo kulture RH, Uprava za zaštitu kulturne baštine, Zagreb, 840-1951 (15. V. 1951.); 878-1951 (23. V. 1951.).

28 Prema jugozapadu, na mjestu nekadašnjeg dvorca, danas stoji hala tvornice »Astra«.

Summary

Andrej Žmegač

Marijana Vojtić

\section{Gornje Oroslavje Castle}

The Gornje Oroslavje Castle was devastated by fire in 1949, and pulled down about ten years later. It had four wings and four cylindrical towers at its corners. After studying the modern architectural plans of the castle made in the years after the Great War, and the 18th centuy descriptions dating from 1746, 1782 and 1797, the authors formulated several hypotheses concerning the construction of the castle and its subsequent extensions. Their research was made more difficult by the fact that the plans available did not contain clear traces of an older nucleus, and indicated that all four wings of the castle had the same type of vaulting (sail vaults on the ground floor, and mirror vaults on the first floor. One of the hypotheses concerning the spatial articulation of the castle at the end of the 18th century is based on the "Josephinian admeasurement", which shows of a three-winged arrangement, with a wall and an entrance from the south-east house front. They also found indications that a projecting structure stood in the south-west wing, perhaps a court chapel. They further concluded that the access to the main entrance to the castle was changed in the nineteenth century, when the castle was accessed in a straight line from the south west, facing the projection. At that time the castle already had all four wings, which were of unequal width. The castle was first owned by the Čikulin and Sermage families, then sold to Ljudevit Vranyczany in 1885. Ljudevit's son Milan left us valuable data concerning the estate and the excellent designs of the castle he made at the turn of the 19th century. In 1921 the castle was purchased by the entrepreneur Prpic, who turned it into a textile mill. This reconstruction was drastic and devastating, damaging most walls and vaults. Only the representative residential front wing was spared. In the remaining wings the original masonry was mostly pulled down and replaced by timber structures, later destroyed by the great fire of 1949 which caused great damage to the castle. 